\title{
Rzecz o bestiach, zgromadzeniach i publicznej partycypacji. Czyli o społecznym wymiarze orzecznictwa Trybunału Konstytucyjnego w analizie na wybranych przykładach
}

\begin{abstract}
Judicial control of the conformity of law to the constitution nowadays serves as one of the basic guarantees of the observance of the constitution. In majority of continental European states it is performed by a particular body - a constitutional court. So the same is true in Poland, however it seems still to be one of the least understood aspects of the functioning of our political system. And especially with regard to the opportunities offered by that for non-public entities to protect their rights and to influence the public decision making process. The awareness in this respect seems to be on a very low level. That is why the aim of the author is to verify a research assumption that the Constitutional Court jurisdiction has a serious social dimension, noticeable for Polish non-public actors.
\end{abstract}

\section{Key words:}

Constitutional Court, constitution, non-state actors, public participation

1 Radosław Potorski, Katedra Europeistyki, Wydział Politologii i Studiów Międzynarodowych, Uniwersytet Mikołaja Kopernika w Toruniu, Polska, potorski@umk.pl. 


\section{ZAGADNIENIA WPROWADZAJĄCE}

Sądowa kontrola zgodności ustaw z konstytucją we współczesnym świecie jest jedną z podstawowych gwarancji przestrzegania konstytucji. W większości państw Europy kontynentalnej jest realizowana przez szczególny organ władzy sądowniczej - sąd konstytucyjny (Garlicki, 2011, s. 355). Powstanie sądów i trybunałów konstytucyjnych szeroko spotykane w II połowie XX wieku zmieniło w istotny sposób życie polityczne i sposób działania mechanizmów państw demokratycznych. Działania tych sądów kompletnie przekształciły problem władzy i jej granic. Kontrola sądów konstytucyjnych zamyka bowiem życie polityczne kraju (w tym podejmowanie decyzji politycznych) w określonych ramach prawnych, gwarantując jednocześnie nadrzędność konstytucji. Można powiedzieć wręcz, że prowadzi to do przekształcenia występujących konfliktów natury politycznej w konflikty dające się rozpatrywać na gruncie prawa, przez co z kolei rozwiązywane są one za pomocą odpowiednich procedur i z poszanowaniem odpowiednich reguł, w tym przede wszystkim zapisów konstytucji (zob. Skrzydło, 2002, s. 485).

Jest to zagadnienie tak istotne, jeżeli wziąć pod uwagę, nie negowaną już dziś, konieczność należytego respektowania katalogu praw człowieka, w ramach działalności każdego państwa legitymującego się demokratycznym systemem sprawowania rządów (zob. Ławniczak, 2010, s. 140-177; Banaszak, 2010, s. 300-305). Zadania jednakże o tyle delikatnego, co i trudnego, albowiem te właśnie prawa (człowieka) z pewnymi wyjątkami nie mają charakteru absolutnego. Wyjątki są dwa: prawo do życia oraz zakaz tortur. Wszystkie pozostałe prawa, np. wolność słowa, sumienia czy prawo do prywatności, mogą podlegać ograniczeniom, ale tylko wtedy, gdy te ograniczenia służą interesowi publicznemu i są wprowadzone na drodze ustaw. A właśnie zgodność tych ustaw z konstytucją ocenia Trybunał Konstytucyjny (Bodnar, 2016, s. 20; Kuciński, 2003, s. 106; Piotrowski, Ochman, Pisz, 2014, s. 16-26; Jarosz-Żukowska, 2010, s. 112-137).

Należałoby zatem uznać, że jest to znaczący element ochrony systemu demokratycznego państwa prawa, który wzmacniać powinien pozycję obywatela, czy też szerzej podmiotów niepublicznych, na drodze ku realizacji ich celów i zaspakajaniu potrzeb. Uwaga o tyle, jak się wydaje trafna, jeżeli zdać sobie sprawę, że niejednokrotnie podmiotami, które mogą stać im na przeszkodzie, mogą okazywać się właśnie rodzime organy władzy, mające niekiedy sprzeczne z nimi, czy z częścią z nich, interesy. Chodzi tu np. o podniesienie skuteczności w zapewnianiu bezpieczeństwa publicznego, czy też ograniczenie poszczególnych wydatków socjalnych w celu utrzymywania odpowiedniego poziomu finansów państwa. Jeżeli odbywa się to w zgodzie z prawem, wówczas jest to kwestia 
do załatwienia na poziomie dyskusji politycznej. Jeżeli jednak organy władzy starają się realizować swoje cele z naruszeniem praw obywateli (czy też szerzej podmiotów niepublicznych - tak osób fizycznych, jak i prawnych), wówczas kluczowe może okazać się funkcjonowanie, umocowanego konstytucyjnie, swego rodzaju hamulca, który mógłby przeciwstawić się podmiotom władzy, jeśli te chciałyby wdrożyć do systemu prawnego przepisy naruszające uprawnienia rządzonych. Jeżeli bowiem przyjąć, że rządzenie to relacja pomiędzy rządzącymi a rządzonymi właśnie (Kaźmierczak, 2011, s. 83-99), to TK stanowiłby jednego z najistotniejszych arbitrów nienadużywania pozycji przez silniejszą ze stron. Przy takim założeniu sprawnie działający TK jest więc warunkiem sine qua non dla należytego realizowania mandatu społecznego rządzących do sprawowania władzy, zwłaszcza w ramach stanowionych ustaw. Można nawet powiedzieć, że należycie funkcjonujący TK jest jednym z zasadniczych gwarantów tego, co m.in. Hubert Izdebski nazywa prawem do dobrego rządzenia (right to good governance). W skład którego wchodziłoby, obok niekwestionowanego prawa do sądu, prawo do nie tylko poprawnego czy przyzwoitego, lecz i dobrego prawa (oczywiście prawa stanowionego) oraz prawo do dobrej administracji (Izdebski, Wykład 2012). Można by zatem powiedzieć, że Trybunał Konstytucyjny powinien być jednym z lepiej poznanych organów w ramach struktury działania państwa, a umiejętność korzystania z jego potencjału kompetencyjnego powinna leżeć w najlepiej pojętym interesie społecznym, jeśli stawianym sobie celem rozwojowym miałoby być aktywne społeczeństwo, zainteresowane udziałem w kreowaniu decyzji publicznych. A przyjąć należy, że tak właśnie jest w nowoczesnych społeczeństwach państw demokratycznych (zob. Kaźmierczak, 2011, s. 94-99).

W świetle poczynionych uwag nasuwają się zatem konkretne pytania. Przede wszystkim: czym dokładnie jest wspominany powyżej mechanizm konstytucyjnej ochrony ze strony TK. A także czy w rodzimych warunkach jest on jedynie konstrukcją teoretyczną, czy też rzeczywiście istnieje możliwość by był on przydatny dla poszczególnych obywateli. Celem niniejszego badania jest zatem analiza społecznego wymiaru ochrony konstytucyjnej prowadzonej przez Trybunał Konstytucyjny.

W związku z powyższym merytoryczny zakres pola zawężony zostaje, co oczywiste, do działalności orzeczniczej TK, ale z uwzględnieniem, że dla wyrazistości argumentacji powinno ono mieć jasno dający się zidentyfikować skutek ogólnospołecznej ochrony konstytucyjnej. Na podstawie wstępnej analizy dokonanej przez autora wysunąć należy twierdzenie, że kategoria ta nie jest jednakże jednolita. Na tym etapie przyjęte zostanie założenie, iż będzie odnosić się ona do przypadków wyroków TK, które będą kwalifikować się do jednej z następujących 
grup. Po pierwsze, gwarantują pewność prawa i stabilność systemu politycznego. Po drugie, wyraźnie powstrzymywały władze publiczne, które za pomocą przepisów prawa chciały wprowadzić dyrektywy postępowania ograniczające uprawnienia podmiotów niepublicznych. I wreszcie, dają tym drugim argumenty prawne w walce o swoje uprawnienia z organami władzy publicznej lub też z podmiotami, wobec których stoją na znacząco słabszej pozycji. Jednym zatem z zadań badawczych będzie odnalezienie rozstrzygnięć TK spełniających tak określone warunki. Dopuścić należy jednak możliwość modyfikacji tego katalogu (w tym jego poszerzenia), w trakcie samego badania, jeśli przemawiać za tym będą pozyskane informacje. Z kolei czasowy zakres pola badawczego rozciągnięty zostanie na pełen okres, od kiedy TK uzyskał pełnię swoich możliwości². Dla rzetelności prowadzonego badania analiza odbywać będzie się dwuetapowo. Pierwszym etapem będzie odnalezienie egzemplifikacji w zakresie jednej ze wskazanych grup orzeczeń TK. Miałaby ona cechować się dużym znaczeniem merytorycznym, ale być także wyraźnie nagłośniona w mediach. Pozwoli to odwołać się w pewnym stopniu do wiedzy powszechnej i dzięki temu jasno zobrazować przyjęty tok rozumowania. Następnie, jeżeli warunek ten nie zostanie spełniony w ramach jednego z przytoczonych rozstrzygnięć, autor stawia sobie za cel odnalezienie orzeczenia o podobnym charakterze, datującego się na czas najnowszej historii TK i przede wszystkim wzrostu natężenia sporu, co do jego działalności. Pozwoli to wykazać z kolei, czy analizowany aspekt funkcjonowania TK (społeczny wymiar ochrony konstytucyjnej) uległ zmianom.

Metodą zastosowaną do realizacji tego celu będzie przede wszystkim wykładnia tekstu prawnego, ale także analiza opracowań doktryny. Zastosowana zostanie także selekcja wstępna, będąca rezultatem zwiadu badawczego, wynikającego z działalności naukowej autora.

\section{ISTOTA DZIAŁALNOŚCI TRYBUNAŁU KONSTYTUCYJNEGO}

\subsection{KOMPETENCJE I CEL DZIAŁALNOŚCI TK}

Sądownictwo konstytucyjne nie istniało w Polsce przed II wojną światową. Po jej zakończeniu na terenie RP zaczęły obowiązywać wzory radzieckie, a w szczególności zasada tzw. jednolitości władzy państwowej, jednoznaczna z odrzuceniem

2 Od 1997 roku, kiedy to sejm utracił możliwość podważania pewnych jego wyroków. Mowa będzie o tym w dalszej części rozważań. 
zasady podziału władz i deklarująca najwyższą, suwerenną pozycję jednoizbowego parlamentu w systemie konstytucyjnych organów państwa. Potrzeba powołania sądownictwa konstytucyjnego była jednakże podnoszona przez rodzimą doktrynę. Zwłaszcza od początku lat 70. XX w. Niemniej dopiero czas silnego oddziaływania „Solidarności” przyczynił się do faktycznych ruchów władz zmierzających do utworzenia takiego ciała. Były one jednak i tak odsuwane w czasie. Choć prace ekspertów rozpoczęły się już w 1981 r., a stosowna nowelizacja ówczesnej konstytucji przyjęta została 26 marca 1982 r. to właściwa ustawa o Trybunale Konstytucyjnym została uchwalona dopiero 29 kwietnia 1985 r. (Garlicki, 2011, s. 356; Kuciński, 2003, s. 320). Podkreślenia wymaga fakt, że wspomniana ustawa ciągle jednak nie pozwalała w pełni realizować zadań, jakie mają do spełnienia organy tego rodzaju. Najważniejsze ograniczenie jego faktycznej pozycji i kompetencje polegały na tym, że tylko niektóre orzeczenia Trybunału były ostateczne. Tak stanowiła przywołana nowelizacja konstytucji z 1982 r. (Ustawa 1982/83). Orzeczenia o niekonstytucyjności ustawy podlegały bowiem rozpatrzeniu przez Sejm, który mógł je odrzucić uchwałą podjętą większością 2/3 głosów (patrz Konstytucja PRL, stan na 1982 rok). Dalej idące zmiany stały się możliwe dopiero po 1989 r. Choć należy przyznać, że polski ustawodawca stosunkowo długo zwlekał z wprowadzeniem pożądanego stanu rzeczy. Właściwa zmiana wprowadzona została dopiero 17 października 1997 r., czyli w momencie wejścia w życie konstytucji z 2 kwietnia 1997 r. (Konstytucja RP) i ustawy z 1 sierpnia 1997 o Trybunale Konstytucyjnym (Ustawa 1997/643), dostosowanej do nowego stanu regulacji konstytucyjnej (Garlicki, 2011, s. 356).

Zgodnie ze zdaniem dominującej części doktryny, uwzględniając art. 10 ust. 2 konstytucji, Trybunał należy traktować jako organ władzy sądowniczej. Gwoli ścisłości należałoby zaznaczyć, że istnieją autorzy, którzy ujmują rolę TK jako oddzielnego podmiotu kontroli w państwie, czy też sądu posiadającego atrybuty szczególnego rodzaju (więcej na ten temat zob. Kuciński, 2003, s. 321) ${ }^{3}$. Nie podlega natomiast dyskusji, że pozycję ustrojową Trybunału Konstytucyjnego charakteryzuje przede wszystkim zasada niezależności. Ma on być niezależny od

3 Przywołania jedynie wymaga rozróżnienie sądów i trybunałów. Sądy tworzą system organów powołanych do „sprawowania wymiaru sprawiedliwości” według terminologii art. 175 ust. 1 konstytucji, tj. orzekania w sprawach indywidualnych. Trybunał Konstytucyjny i Trybunał Stanu pozostają poza systemem sądów, tworząc drugi, odrębny segment władzy sądowniczej (patrz Kuczyński, s. 321). W ramach władzy sądowniczej zajmuje on pozycję odrębną zarówno wobec Trybunału Stanu, jak i sądów, z Sądem Najwyższym i Naczelnym Sądem Administracyjnym na czele. Nie istnieją też żadne związki pomiędzy Trybunałem Konstytucyjnym a Krajową Radą Sądownictwa (Garlicki, 2011, s. 357). 
władzy ustawodawczej i władzy wykonawczej (zarówno jednak sejm, jak i prezydent dysponują pewnymi uprawnieniami kreacyjnymi wobec TK) (Garlicki, 2011, s. 357). Jest to także podstawa sensu jego funkcjonowania i gwarancja możliwości należytego sprawowania powierzonej mu funkcji strażnika poprawności działania tychże pionów władzy. Jest to tym samym jeden z przejawów realizacji zasady podziału władz i postawienia zasady zwierzchnictwa konstytucji ponad polityczną swobodą działania aktualnej większości parlamentarnej.

Takie umocowanie systemowe ma zapewnić lepszą realizację podstawowych zadań Trybunału. A zgodnie z ustawą zasadniczą należą do nich:

- kontrola norm prawnych pod względem ich zgodność z konstytucją;

- rozstrzyganie sporów kompetencyjnych pomiędzy centralnymi konstytucyjnymi organami państwa (Konstytucja RP, Art. 189);

- orzekanie o zgodności z Konstytucją celów lub działalności partii politycznych (Konstytucja RP, Art. 188 pkt 4);

- uznawanie przejściowej niemożności sprawowania urzędu przez prezydenta (Konstytucja RP, Art. 131 ust. 1).

Każde z wymienionych uprawnień jest istotne. Uznanie celów lub działalności partii politycznej za niezgodne z konstytucją stwarza kompetencje do eliminacji z życia publicznego organizacji o charakterze sprzecznym z podstawowymi zasadami ustroju państwa (zob. Uliasz, 2011, s. 100; Piotrowski i in., 2014, s. 157). Z kolei rozstrzyganie sporów kompetencyjnych daje możliwość ochrony i gwarancji, przestrzegania i nieprzekraczania swoich kompetencji przez organy władzy (Skrzydło, 2002, s. 485). Ma to duże znaczenie dla podmiotów niepublicznych, gwarantując im odpowiednią ochronę przed nadużywaniem pozycji ze strony władz publicznych (zwłaszcza ustawodawcy), a także gwarantuje im pewność i przewidywalność ustrojową (Garlicki, 2011, s. 371-373; Kustra, Bień-Kacała, 2009, s. 515-518) ${ }^{4}$. Niemniej najważniejszym z uprawnień TK pozostaje kontrola hierarchicznej zgodności norm prawnych (i w razie konieczności stosowanie zasady lex superior derogat legi inferiori). Jest to więc rozstrzyganie o tym, czy normy prawne niższego rzędu są zgodne z normami prawnymi wyższego rzędu (a zwłaszcza z konstytucją) i w miarę potrzeby eliminowanie norm niezgodnych z systemu obowiązującego prawa. Istotne jest, iż polski system kontroli norm zdecydowanie preferuje kontrolę a posteriori, tj. następczą. Co znaczy, że zasadniczo może dotyczyć tylko aktów normatywnych, które już zostały ustanowione albo

4 Uznanie przejściowej niemożności sprawowania urzędu przez prezydenta jak do tej pory nie miało miejsca, więc potraktowane zostało informacyjnie w ramach niniejszej analizy. Więcej natomiast zob. w: Piotrowski i in., 2014, s. 156-157. 
już nabrały mocy obowiązującej, albo znajdują się jeszcze w okresie vacatio legis (Konstytucja RP, art. 188 pkt 1-3). Tylko wyjątkowo kontrola norm może przybrać charakter prewencyjny - a priori, tj. uprzedni (Konstytucja RP, art. 122 ust. 3 i 4, art. 133 ust. 2), a jedynym podmiotem uprawnionym do jej inicjowania jest prezydent Rzeczypospolitej Polskiej (zob. Kustra, Bień-Kacała, 2009, s. 496-497). Na szczególną uwagę, z racji obranego problemu badania, zasługuje tu natomiast tzw. skarga konstytucyjna. Zgodnie z normą art. 79 ust. 1 konstytucji, „każdy [a więc także i podmiot niepubliczny - dop. aut.], czyje konstytucyjne wolności lub prawa zostały naruszone, ma prawo, na zasadach określonych w ustawie, wnieść skargę do Trybunału Konstytucyjnego w sprawie zgodności z konstytucją ustawy lub innego aktu normatywnego, na podstawie którego sąd lub organ administracji publicznej orzekł ostatecznie o jego wolnościach lub prawach albo o jego obowiązkach określonych w konstytucji”. Jest to zatem bezpośrednie połączenie proceduralne pomiędzy podmiotami niepublicznymi a organem orzekającym bezpośrednio odnośnie do obowiązywania norm prawnych w ramach naszego systemu prawnego (Granat, 2002, s. 494). Z tych właśnie względów działalność sądów konstytucyjnych jest czasem określana mianem negatywnego ustawodawcy, bowiem, tak jak polski Trybunał Konstytucyjny, eliminują one przepisy niekonstytucyjnych ustaw z systemu obowiązującego prawa (Garlicki, 2011, s. 357). Należy zatem zgodzić się, że jest to ogromna kompetencja w zakresie wpływu na kształt polityk publicznych w państwie.

\section{2 . BUDOWA TRYBUNAŁU KONSTYTUCYJNEGO}

W skład Trybunału Konstytucyjnego wchodzi piętnastu sędziów, wybieranych przez Sejm na dziewięcioletnią kadencję (Konstytucja RP, Art. 194 ust. 1). Ustawa zasadnicza z 1997 r. wprowadziła wybór indywidualny, co oznacza, że każdy sędzia jest wybierany na dziewięć lat, nawet jeżeli zajmie miejsce sędziego, który odszedł z Trybunału Konstytucyjnego przed upływem swojej kadencji. Kandydatów na stanowisko sędziego może przedstawić grupa co najmniej 50 posłów lub prezydium sejmu ${ }^{5}$. Kandydatem może zostać tylko osoba, która wyróżnia się wiedzą prawniczą oraz posiada kwalifikacje wymagane do zajmowania stanowiska sędziego Sądu Najwyższego lub NSA. Doktryna wskazuje już od pewnego czasu, że taki sposób

5 Z kolei Prezes i Wiceprezes Trybunału są powoływani przez Prezydenta Rzeczypospolitej spośród kandydatów przedstawionych na każde z tych stanowisk przez Zgromadzenie Ogólne Sędziów Trybunału (Konstytucja RP, Art. 194 ust. 2). Prezes Trybunału reprezentuje Trybunał na zewnątrz oraz wykonuje czynności związane z bieżącym organizowaniem pracy Trybunału i kierowaniem aparatem wykonawczym. 
wyłaniania sędziów czyni wciąż ten wybór uzależniony od aktualnie panującej większości sejmowej, nawet biorąc pod uwagę wysokie wymagania oraz zwyczaj legitymowania się znacznym dorobkiem naukowym kandydata. Proponowanym rozwiązaniem jest często postulat wprowadzenia głosowania nad poszczególną kandydaturą większością kwalifikowaną, co dawałoby konieczność osiągnięcia pewnego konsensusu, a za tym znaczną gwarancję apolityczności kandydata (zob. np. Garlicki, 2011, s. 358).

Dla pozycji i sposobu funkcjonowania Trybunału zasadnicze znaczenie ma fakt, że składa się on - podobnie jak inne organy władzy sądowniczej - z niezawisłych sędziów. Z formalnego punktu widzenia, jak określa to art. 195 ust. 1 konstytucji, „W sprawowaniu swojego urzędu są niezawiśli i podlegają tylko konstytucji”. Z tego właśnie względu sędziom Trybunału Konstytucyjnego przysługuje zestaw pewnych praw, ale i ciążących na nich obowiązków (czy raczej zakazów). Przede wszystkim poważnym przywilejem jest immunitet ukształtowany właściwie identycznie jak immunitet sędziego (Konstytucja RP, Art. 196) ${ }^{6}$. Istotną gwarancją niezawisłości jest zakaz wybierania sędziego na kolejną kadencję (Konstytucja RP, Art. 194 ust. 1 zdanie 2) oraz zakaz usunięcia ze stanowiska w trakcie kadencji. Wygaśnięcie mandatu sędziego może nastąpić jedynie wskutek enumeratywnie wskazanych przypadków, jak: śmierć, zrzeczenie się urzędu czy skazanie prawomocnym wyrokiem sądu za przestępstwo. $Z$ drugiej natomiast strony dla rzetelności sprawowania swojej funkcji sędziowie Trybunału nie mogą łączyć swego urzędu z innymi stanowiskami w aparacie państwowym. Zastosowanie wobec nich ma również zasada apolityczności. Oznacza to m.in. zakaz przynależności do partii politycznych, związków zawodowych oraz prowadzenia działalności publicznej niedającej się pogodzić z zasadami niezależności sądów i niezawisłości sędziowskiej (Konstytucja RP, Art. 195 ust. 3). Co więcej, w praktyce większość sędziów TK rekrutuje się spośród profesorów prawa, co odróżnia ten sąd zarówno od Sądu Najwyższego, jak i od Naczelnego Sądu Administracyjnego, a tym bardziej od innych sądów. Wnosi to jednocześnie pewną specyfikę do sposobu działania oraz jakości dokonywanej wykładni prawa przez Trybunał (Garlicki, 2011, s. 358).

6 Oczywiste różnice wynikają jedynie ze specyfiki budowy Trybunału i dotyczą organów uprawnionych do odebrania takiego immunitetu. 


\section{WYROKI TK O ZNACZENIU SPOŁECZNYM - WYBRANE PRZYKŁADY}

Powyższe rozważania wskazują, że TK posiada odpowiednią budowę oraz zakres kompetencji, aby mógł realizować zadania z zakresu ochrony konstytucyjności porządku prawnego. Zakładać można, że skutkować powinno to także wprowadzaniem ochrony konstytucyjnej w wymiarze społecznym. Zgodnie jednak z przyjętym planem badania należy sprawdzić, czy faktycznie dochodziło do takich przypadków i na czym miałoby to polegać w praktyce.

Zasadne wydaje się by w pierwszej kolejności uwagę skupić na rozstrzygnięciach Trybunału, które odnosiły się do fundamentalnych zasad stabilizujących porządek prawny w Polsce. To w nich poruszają się i prowadzą swoją aktywność podmioty niepubliczne. To w przestrzeni tak ustalonych ram starają się także ewentualnie wywierać wpływ na podejmowane decyzje polityczne. Co znaczące, odnalezienie orzeczeń kwalifikujących się do tej kategorii nie nastręcza znacznych trudności. Wskazać bowiem można tu np. rozstrzygnięcie z 11 maja 2005 r. uznające traktat z 16 kwietnia 2003 r. podpisany w Atenach (Traktat Akcesyjny) za zgodny z konstytucją. Tym samym przypieczętowane zostało związanie polskich podmiotów regulacjami wydawanymi w ramach systemu UE (Wyrok TK 2005a, pkt 1 sentencji). Innym przykładem może być z kolei wyrok z 27 kwietnia 2005 r., w którym Trybunał wskazał z kolei granicę przychylności wobec prawa unijnego. Uznał bowiem, że akty prawne implementujące prawo unijne do polskiego porządku prawnego muszą być zgodne z polską konstytucją (Wyrok TK 2005b, Pkt III 2.4., III 3.3., III 5.3.). Co oznacza tyle, że w hierarchii źródeł prawa, nawet po akcesji do Unii, najwyższym aktem w Polsce pozostaje konstytucja. Wszystkie stosunki społeczne, regulowane prawnie, mogą zatem opierać się na przepisach unijnych, ale tylko tak dalece jak pozostają one w zgodzie z zapisami rodzimej ustawy zasadniczej (szerzej na temat szczegółowych problemów podnoszonych przez TK w tej sprawie zob. Potorski, 2011, s. 189-198). Do tej grupy orzeczeń zaliczyć można także wyrok z dnia 16 marca 2011 r., którym Trybunał uznał dekret z grudnia 1981 r. o stanie wojennym za niezgodny z art. 7 konstytucji Rzeczypospolitej Polskiej w związku z art. 31 ust. 1 konstytucji Polskiej Rzeczypospolitej Ludowej z 1952 r. (Wyrok TK 2011, Pkt 1 sentencji orzeczenia). Miał on charakter wyraźnie odnoszący się do wydarzeń przeszłych, ale wydaje się, że wyraźne rozstrzygnięcie o braku konstytucyjności tego aktu zapewnia poczucie sprawiedliwości społecznej oraz - o czym była tu mowa - pewności prawa.

Z kolei drugą ze wspomnianych grup orzeczeń miałyby być te, poprzez które TK wyraźnie korygował dyrektywy postępowania, określane przez regulacje prawne, ograniczające de facto uprawnienia podmiotów niepublicznych. I tu jednym 
z pierwszych orzeczeń, które należałoby wymienić, jest to z dnia 18 września 2014 r. w sprawie nowelizacji ustawy - prawo zgromadzeń. Trybunał Konstytucyjny rozpoznał połączone wnioski dwóch grup posłów na Sejm oraz RPO dotyczące znowelizowanych przepisów Ustawy z dnia 5 lipca 1990 r. Prawo o zgromadzeniach (Ustawa 2013/397) określających m.in. definicję zgromadzenia publicznego poprzez wskazanie minimalnej liczby jej uczestników, zasady odbywania się kilku zgromadzeń w tym samym czasie lub miejscu, graniczny termin notyfikacji zgromadzenia publicznego do władz lokalnych oraz procedury odwoławczej w przypadku decyzji odmownej. TK podkreślił przede wszystkim, że prawo do publicznego głoszenia swoich opinii jest jednym z podstawowych praw wynikających z ustawy zasadniczej. Uznał, że zgodnie z art. 57 konstytucji każdemu zapewnia się wolność organizowania pokojowych zgromadzeń i uczestniczenia w nich (Wyrok TK 2014, Pkt III. 2.1. uzasadnienia) ${ }^{7}$. Czyniąc to założenie podstawą swoich wywodów, TK dopatrzył się kilku zasadniczych błędów w przedmiotowych regulacjach. Stwierdził przede wszystkim, że ustawowa definicja zgromadzenia, jako zgrupowania obejmującego co najmniej 15 osób, wprowadza element konstrukcyjny nieprzewidziany na gruncie konstytucyjnym. Zgromadzeniem publicznym są także te pokojowe zgrupowania, których liczba uczestników nie spełnia tego kryterium (Wyrok TK 2014, Pkt. III 4.2. oraz 4.3. uzasadnienia). W ocenie Trybunału wydłużenie terminu notyfikacji do organu gminy woli zorganizowania zgromadzenia do minimum 3 dni roboczych nie jest konieczne w demokratycznym państwie prawnym (Wyrok TK 2014, Pkt III.6.5. uzasadnienia). TK dodał także, że uzasadnione jest żądanie zmiany parametrów planowanego zgrupowania od podmiotu, który w danych warunkach później notyfikował swoje zamiary właściwemu organowymi władzy publicznej. Jednakże to na organach władzy publicznej ciąży obowiązek wykazania, że w danych okolicznościach mamy faktycznie do czynienia z niemożliwą do usunięcia kolizją w sferze realizacji tej samej wolności. A dopiero stwierdzenie braku możliwości rozwiązania konfliktu otwiera dopuszczalność zastosowania dalszej części procedury przewidzianej przez ustawodawcę, zakładającej podjęcie określonych działań - tym razem - przez organizatorów planowanych zgromadzeń (Wyrok TK 2014, Pkt III. 9.3., 9.4. uzasadnienia). Ważkość tego orzeczenia wynika z faktu, że

7 Nawiązując w tym kontekście do treści art. 57 w związku z art. 31 ust. 3 konstytucji, należy stwierdzić, że wszelkie ograniczenia mogą być ustanowione tylko w ustawie, jedynie jeżeli jest to konieczne w demokratycznym państwie dla ochrony bezpieczeństwa państwa lub porządku publicznego, ochrony środowiska, zdrowia i moralności publicznej bądź wolności i praw innych osób. Ograniczenia nie mogą przy tym sięgać tak daleko, aby naruszać istotę danej wolności bądź prawa (Wyrok TK 2014, Pkt III.3.1. uzasadnienia). 
odnosiło się ono do jednych z ważniejszych praw politycznych we współczesnych państwach demokratycznych. Jak stwierdził sam TK, realizowanie wolności zgromadzeń w przestrzeni publicznej jest konieczne dla prawidłowego funkcjonowania wspólnoty politycznej. Ma ona także poważną funkcję partycypacyjną, której nie można ignorować. Wiąże się ona bowiem z możliwością wpływania jednostek na proces decyzyjny oraz kształtowanie woli politycznej niezależnie od istniejącego mechanizmu przedstawicielskiego, a więc w okresach między poszczególnymi aktami wyborczymi. Dzięki temu także organy przedstawicielskie mogą poznać źródła napięć wywołujących sprzeciw członków społeczeństwa w odniesieniu do konkretnych rozstrzygnięć w przestrzeni publicznej (Wyrok TK 2014, Pkt III. 2.3. uzasadnienia, a także Bodnar, Szwast, 2015).

Z kolei przypadkiem z ostatnich tygodni może być wydany 11 listopad 2016 r. wyrok w sprawie zatrzymywania prawa jazdy. Zaskarżone przepisy zostały wprowadzone do systemu prawa przez ustawę z 20 marca 2015 o zmianie kodeksu karnego oraz niektórych innych ustaw (Ustawa 2015/541), która weszła w życie w maju 2015 r. Jednym z istotnych zarzutów, podniesionych wobec niej przez RPO był fakt, że zawarte tamże przepisy nie dają policji i staroście prawnych możliwości odstąpienia od zatrzymania prawa jazdy z uwagi na zaistnienie okoliczności, którą można byłoby kwalifikować jako stan wyższej konieczności. Trybunał uznał rzeczone przepisy za niezgodne z konstytucją podkreślając, że brak jest w ustawie wyraźnego wskazania, że osoba prowadząca pojazd na obszarze zabudowanym i przekraczającą o $50 \mathrm{~km} / \mathrm{h}$ dopuszczalną prędkość nie popełnia czynu zagrożonego zatrzymania prawa jazdy, jeżeli zdarzenie to następuje w celu „zapobieżenia czy ograniczenia bezpośredniego niebezpieczeństwa grożącego dobru chronionemu prawem, którego to niebezpieczeństwa nie można inaczej uniknąć, a dobro poświęcone w postaci bezpieczeństwa na drodze nie przedstawia wartości oczywiście większej niż dobro ratowane”. Dla jasności TK dodał też, że „powołanie się na stan wyższej konieczności uzasadniający odstąpienie od zatrzymania prawa jazdy osobie, która nadmiernie przekroczyła prędkość, powinno być zastrzeżone przez ustawodawcę tylko dla takiej sytuacji, gdy owo przekroczenie prędkości usprawiedliwione jest potrzebą ratowania życia i zdrowia” (Wyrok TK 2016a, pkt III. 7.4. uzasadnienia).

Kolejną grupą miałyby być natomiast rozstrzygnięcia Trybunału, które dają podmiotom niepublicznym argumenty prawne w walce o swoje uprawnienia z organami władzy publicznej, czy też jednostkami prywatnymi, ale znacznie od nich silniejszymi w ramach stosunków prawnych. Tu na uwagę zasługuje m.in. wyrok z dnia 14 kwietnia 2015. Do TK trafiły bowiem przepisy prawa bankowego (Ustawa 2015/128), stanowiące podstawę tzw. bankowego tytułu egzekucyjnego 
(BTE). Pozwala on bankom w znacznie prostszy sposób (niż poprzez standardową procedurę sadową) windykować przeterminowane długi. Po wystawieniu BTE zwrócić muszą się do sądu jedynie o nadanie klauzuli wykonalności. Dalej sprawa może trafić już do egzekucji komorniczej. Bank może wszcząć egzekucję bez sprawdzenia przez sąd, czy dług rzeczywiście istnieje i czy bank ma prawo domagać się akurat takiej, a nie innej kwoty (Wyrok TK 2015a, Pkt V.2.2. uzasadnienia). TK zauważył, że według tychże przepisów bank zostaje postawiony na pozycji sędziego we własnej sprawie (iudex in causa sua), podczas gdy bank i klient powinni być równymi stronami stosunku prawnego. Co więcej, jak wskazał Trybunał bank uzyskuje tytuł egzekucyjny z pominięciem merytorycznego rozpoznania sprawy, a także nie wymaga się, aby uprzedzał dłużnika, że występuje o taką klauzulę do sądu. Odnosząc się natomiast do zabezpieczenia interesów banków, Trybunał zwrócił również uwagę, że poza BTE dysponują one szerokim zestawem środków zabezpieczenia kredytów w szczególności wekslem, który może stać się podstawą wydania nakazu zapłaty w trybie art. 491 i art. 492 k.p.c. (Wyrok TK 2015a, Pkt. V 3.3.2, V. 3.3.3. uzasadnienia). W związku z tym TK uznał regulujące to przepisy za niekonstytucyjne (Wyrok TK 2015a, Pkt I sentencji).

Drugą z kolei ze spraw, którą należałoby tu przywołać, jest także jedno z najnowszych rozstrzygnięć TK dotyczące tzw. klauzuli sumienia. W swoim wyroku z 7 października 2015 r. Trybunał stanął przed koniecznością dokonania oceny, w jakim zakresie lekarz może powstrzymać się od wykonania świadczenia zdrowotnego niezgodnego z jego sumieniem oraz jak kształtuje się ewentualny obowiązek wskazania realnych możliwości uzyskania takiego świadczenia u innego lekarza lub w innym podmiocie leczniczym. Chodziło tu konkretnie o zapisy ustawy o zawodach lekarza i lekarza dentysty (Ustawa 1996/464, Art. 39). Sędziowie uznali, że prawo do sprzeciwu sumienia powinno być uznane za prawo pierwotne względem jego ograniczeń. Dodali, iż taka właśnie wykładnia prezentowana była w dotychczasowym orzecznictwie TK, który przyjął istnienie w polskim systemie prawnym konstrukcji klauzuli sumienia - w odniesieniu do lekarzy zobowiązanych do wydania orzeczenia o dopuszczalności przerwania ciąży oraz wykonania zabiegu przerwania ciąży - jeszcze przed jej oficjalnym skodyfikowaniem w przepisach rangi ustawowej (Wyrok TK 2015b, Pkt III 4.4.3.uzasadnienia). W związku z powyższym przedmiotowe przepisy uznane zostały za niekonstytucyjne.

Analizując zbiór orzeczeń według obranego czasowego zakresu pola badawczego, z perspektywy społecznego wymiaru ochrony konstytucyjnej sprawowanej przez TK, należy jednak podnieść, że pośród jego rozstrzygnięć można odnaleźć takie, które wzbudzały liczne kontrowersje i długo po wydaniu podlegały jeszcze 
dyskusjom, właśnie z punktu widzenia wymiaru społecznego ich skutków. Jednym z budzących najbardziej skrajne oceny, zwłaszcza w kontekście ochrony uprawnień podmiotów niepublicznych, był wyrok z dnia 4 listopada 2015 r. w sprawie Otwartych Funduszy Emerytalnych (OFE). TK uznał za zgodne z konstytucją przeniesienie części umieszczonych tam środków przyszłych emerytów na rzecz Zakładu Ubezpieczeń Społecznych (zob. Wyrok TK 2015c). Wydając go, Trybunał musiał wziąć pod uwagę bezpieczeństwo finansów publicznych oraz ochronę własności obywateli (siłą rzeczy specyfika emerytury zawężała tu pole tylko do osób fizycznych, z pominięciem prawnych). Kluczową kwestią okazał się zatem prawno-finansowy charakter środków zgromadzonych w OFE. Wydając swój wyrok, Trybunał uznał, że środki pochodzące ze składek ubezpieczeniowych, również zgromadzone w otwartych funduszach emerytalnych, są - w sensie konstytucyjnym - środkami publicznymi, a nie prywatnymi oszczędnościami ubezpieczonych. Pochodzą one bowiem z przymusowej i powszechnej składki emerytalnej, która ma charakter daniny publicznej (Komunikat po Wyroku TK 2015c, ustęp pierwszy) ${ }^{8}$. Należy przyznać jednakże, że i w łonie samego Trybunału sprawa ta wzbudzała kontrowersje, czego dowodem może być niejednomyślna decyzja składu orzekającego oraz umieszczone w pełnej wersji wyroku zdania odrębne. Samo rozstrzygnięcie do tej pory natomiast wywołuje rozbieżne głosy nawet wśród samych ekonomistów (zob. Bankier24, 2015).

Co jednak istotne $\mathrm{z}$ analizowanej perspektywy takie rozstrzygnięcia Trybunału należą do rzadkości. Trzeba odnieść się tutaj bowiem do skali badanego zjawiska. Trybunał Konstytucyjny od początku swojej działalności do bieżącego roku (precyzując do końca maja 2016) wydał już 2537 rozstrzygnięć kończących zawisłe przed nim postępowanie na etapie rozpoznania merytorycznego (TK - statystyka, 2016). A nawet jeśliby chcieć wskazywać te pośród orzeczeń, które wywołują kontrowersje w zakresie odbioru społecznego, trudno odmówić im wysokiej jakości merytorycznej argumentacji przywoływanej przez Trybunał na poparcie swoich ostatecznych twierdzeń. Co więcej, umieszczane zdania odrębne sędziów składu orzekającego są dowodem debaty na najwyższym profesjonalnym szczeblu poprzedzającej wydanie rozstrzygnięcia oraz same stają się istotnym elementem

8 TK dodał także, iż ustawodawca dysponuje stosunkowo szeroką swobodą rozporządzania takimi środkami w celu zapewnienia ubezpieczonym realizacji prawa do emerytury. To bowiem państwo odpowiada wobec obywateli za organizację systemu emerytalnego i wypłatę świadczeń. Nie można jednocześnie zakładać niezmienności unormowań określających warunki nabywania tego prawa, zwłaszcza jeśli zmieniają się warunki społeczno-ekonomiczne - stwierdził Trybunał Konstytucyjny (Komunikat po Wyroku TK 2015c, ustęp pierwszy). 
kształtowania doktryny. Wzmacniają jednocześnie nawyk wielowymiarowego patrzenia na każdą z możliwych wykładni przepisów konstytucji i skłaniają do szerokiego analizowania kolejnych przypadków.

\section{UWAGI KOŃCOWE}

Można zatem powiedzieć, że wskazane orzeczenia stanowią jasny dowód na znaczącą wagę w zakresie wprowadzania społecznego wymiaru ochrony konstytucyjnej przez Trybunał. Analizując pod tym względem działanie systemu prawnego w naszym kraju, można zauważyć jeszcze jeden aspekt poruszanego tematu. Wydaje się dziś nie podlegać dyskusji, że władze publiczne, zwłaszcza władza ustawodawcza, zwracają szczególną uwagę na kompetencje orzecznicze TK (wraz z przedłożoną już wykładnią przepisów ustawy zasadniczej) oraz potencjalne konsekwencje uznania stanowionych przepisów za niekonstytucyjne. Jednym z przykładów poprawności takiego twierdzenia może być sprawa odnosząca się do tzw. ustawy o bestiach z 2014 r. (Ustawa 2014/24). Prace nad niniejszą ustawą zainicjowane zostały perspektywą wyjścia na wolność osób, które w 1989 r. zostały objęte amnestią, a skazane były na karę pozbawienia życia za przestępstwa o szczególnej społecznej szkodliwości. W momencie amnestii w polskim k.k. nie wprowadzona została jeszcze kara dożywotniego pozbawienia wolności, stąd największą możliwą karą izolacyjną, na jaką można było zamienić karę śmierci było 25 lat pozbawienia wolności (patrz k.k. stan na 1989 r.). W związku z powyższym w społeczeństwie rozgorzała dyskusja, jak należy potraktować wychodzącego na wolność pierwszego i najbardziej znanego ze skazanych - Trynkiewicza oraz innych w podobnej sytuacji. Przyznać należy, że prawodawca znajdował się pod ogromną presją szybkiego i kategorycznego zapewnienia bezpieczeństwa publicznego. Domagano się m.in. ponownego skazania Trynkiewicza, czy też przedłużenia mu wyroku lub zamiany go na dożywocie. Prawodawca przyjął jednakże rozwiązanie w postaci przywołanej ustawy o bestiach. Umożliwia ona na mocy decyzji sądu cywilnego zastosowanie - na wniosek dyrektora zakładu karnego - wobec takiej osoby, już po odbyciu przez nią kary więzienia (w systemie terapeutycznym), nadzoru prewencyjnego lub leczenia w ośrodku zamkniętym. Analizując uzasadnienie do przedmiotowej ustawy, można odnieść wrażenie graniczące z pewnością, że prawodawca starał się uniknąć właśnie sprzeczności wprowadzanych regulacji z wykładnią TK w sprawie m.in. nieretroaktywności prawa karnego (Druk Sejmowy 1577, 2013, s. 1-2 uzasadnienia). Podobne twierdzenia można odnaleźć także w stanowisku doktryny, która to też dość jasno 
wskazywała, że wprowadzane prawo zdaje się chronić interes publiczny, ale ociera się jednakże o naruszenie reguły dobrej legislacji (np. Krawczyk, 2014). Można jednak zakładać, że te właśnie starania ustawodawcy przeważyły w decydującym momencie. Zgodnie bowiem z przewidywaniami wspomniana ustawa skierowana została do kontroli przed TK, a ten w swoim wyroku z dnia 23 listopada 2016 r. uznał większość jej zapisów za zgodne z konstytucją (Wyrok TK, 2016b). Można zatem powiedzieć, że mamy tu do czynienia z tym, co w doktrynie nazywane jest niekiedy chilling effect, czyli efektem mrożącym, czy też prewencyjnym. Oznacza on tyle, że ustawodawca powstrzymuje się od przyjmowania, czy też w ogóle od składania projektów, które byłyby sprzeczne z orzecznictwem Trybunału (Sześciło, 2016). Ten rodzaj oddziaływania TK można by potraktować wręcz jako kolejny rodzaj ścieżki zapewniania społecznego wymiaru ochrony konstytucyjnej przez Trybunał. Trudno bowiem byłoby odszukać, ile faktycznie razy jego sama obecność oraz dotychczasowa aktywność powstrzymały władze publiczne przed wydaniem prawa naruszającego konstytucyjne prawa rządzonych.

Co więcej, obecny tok rozumowania pozwala stwierdzić, że świadomość możliwości i potencjału decyzyjnego TK po stronie władz publicznych jest dostrzegalna, tak samo jak pewne nawyki postępowania w związku z tak przedstawiającą się rzeczywistością. W kontekście analizowanego zagadnienia należałoby jednakże zapytać, jak w tym zakresie kształtuje się kultura polityczna w naszym kraju. Rozumiana tu podobnie jak u Czesława Mojsiewicza jako znajomość przez społeczeństwo norm, zasad, praw rządzących rozwojem społecznym i polityką, pozwalających na ocenę postępowego lub wstecznego charakteru polityki i sił tworzących i realizujących określoną politykę. Przejawiająca się w sposobie zachowania politycznego, w stopniu udziału w życiu politycznym państwa oraz w formach realizacji interesu określonych grup w danym okresie historycznym (podawane za: Garlicki, Noga-Bogomilski, 2004, s. 36) ${ }^{9}$. I tu niestety należy wyraźnie skłonić się ku tezie, że społeczeństwo w Polsce - pomimo już ponad ćwierćwiecza od zmiany systemu - dopiero uczy się poruszania po ścieżkach tworzonych w systemie demokratycznym. Dopiero poznajemy przysługujące nam

9 Podobnie zresztą określają ją Garlicki i Noga-Bogomilski, gdy uznają, że jest to zmienny w czasie - wytworzony głównie pod wpływem tradycji historycznej oraz struktury instytucji politycznych i zasad funkcjonowania danego systemu - całokształt orientacji społeczeństwa, grupy społecznej, jednostek wobec polityki. Są to wewnętrzne przekonania znajdujące wyraz w zachowaniach konkretnych i werbalnych. Składają się na nie: zainteresowania polityką, wiedza o niej i znajomość faktów politycznych; wartości uznawane i pożądane dotyczące systemu politycznego i mechanizmów funkcjonowania jego instytucji; ocena zjawisk politycznych i sądów wartościujących na temat instytucji politycznych; uznawane wzory zachowań w sferze polityki i wypróbowane typy działań politycznych (Garlicki, Noga-Bogomilski, 2004, s. 44-45). 
możliwości i formy wpływania, poza samym aktem wyborczym, na kształtowanie decyzji publicznych. Uczymy się tego, co nazywane jest partycypacją publiczną. Nie jest to jednak zadanie łatwe. Wymaga bowiem dobrej znajomości określonych mechanizmów. A w tym przypadku, mowa jest o działalności jednego z najbardziej wyspecjalizowanych organów sądowych, zajmujących się nierzadko zróżnicowaną i skomplikowaną materią, interpretując ją także w ujęciu abstrakcyjnym. Po to, by należycie się z nią zaznajomić, konieczna jest zatem podstawowa wiedza z zakresu systemu prawnego, zwłaszcza ustrojowego, ale też i przepisów innych gałęzi dla zrozumienia kontekstu wywodzonych interpretacji. Potrzebne jest też ogólne rozumienie zasad funkcjonowania systemu politycznego, w tym pewności i przewidywalności prawa, istoty i sensu reguł ograniczających władze publiczne w systemie demokratycznym i kanonu struktur ochrony praw podmiotów niepublicznych. Z drugiej natomiast strony nie można w takim przypadku wysuwać postulatów wyłącznie w kierunku obywateli (czy też szerzej sektora niepublicznego), wymagając, by samoistnie stali się „uzbrojonym” w specjalistyczną wiedzę, aktywnym partnerem dla władz, społeczeństwem partycypującym. Jak najbardziej uprawnionym wydaje się w tym momencie przytoczenie i przyłączenie się do postulatu wyrażanego przez część doktryny prawniczej, a nawet przez samych sędziów TK. Tak np. prof. Ewę Łętowską, która wielokrotnie postulowała o bardziej przystępne prezentowanie głównych tez orzeczeń Trybunału. Odnosząc się właśnie do społecznego wydźwięku i konsekwencji prezentowanych rozstrzygnięć, apelowała o podawanie meritum decyzji, nie tyle w języku kategorii prawnych, ile w ramach prostego, ale klarownego przekazu bazującego na wskazywaniu podstawowych praw konstytucyjnych, które zostały w danym przypadku zagrożone i ochronione. Tak, by potencjalny odbiorca mógł zrozumieć, jakie mechanizmy zostały uruchomione oraz jakie były ku temu przesłanki (Łętowska, 2016).

Tytułem podsumowania można zatem stwierdzić, że w ramach przeprowadzonej analizy udało się potwierdzić postawione na wstępie założenie badawcze. Trybunał Konstytucyjny ma faktyczną możliwość, by realizować społeczny wymiar ochrony konstytucyjnej. Sam katalog możliwych rodzajów oddziaływania przez TK we wspomnianym zakresie został nawet poszerzony o jeden wariant (tzw. chilling effect). Z kolei wysunięte postulaty, choć niezwykle trudne do zrealizowania w założeniu, mogą przyczynić się do poprawy kultury politycznej w Polsce i budowy społeczeństwa korzystającego w większym stopniu z partycypacji publicznej. 


\section{Literatura:}

Banaszak, B. (2010). Zasada demokratycznego państwa prawnego a kwestia praw i wolności jednostki. W: M. Jabłoński (red.), Wolności i prawa jednostki w Konstytucji RP. Tom I, Idee i zasady przewodnie konstytucyjnej regulacji wolności praw jednostki w RP (s. 300-317). Warszawa: Wyd. C.H BECK.

Bodnar, A. (2016). Wolności w niebezpieczeństwie. Newsweek, 48.

Bodnar, A., Szwast, M. (2015). Wolność zgromadzeń publicznych w Polsce po wyroku Trybunału Konstytucyjnego z 18 września 2014 r. Analizy i Rekomendacje, 2. Pobrane z: http://www.hfhr.pl/wp-content/uploads/2015/02/hfpc_analizy_i_rekomendacje_22015. pdf.

Dekret (1981/154) z dnia 12 grudnia 1981 o stanie wojennym, Dz.U. RP z 1981 Nr 29 poz. 154.

Druk Sejmowy 1577 VII kadencja Sejmu RP z dnia 17 lipca 2013, RM-10-58-13, Projekt ustawy o postępowaniu wobec osób z zaburzeniami psychicznymi stwarzających zagrożenie życia, zdrowia lub wolności seksualnej innych osób. Pobrane z: http:// www.sejm.gov.pl/Sejm7.nsf/druk.xsp?nr=1577.

Garlicki, J., Noga-Bogomilski, A. (2004). Kultura polityczna w społeczeństwie demokratycznym. Warszawa: Instytut Nauk Politycznych UW.

Garlicki, L. (2011). Polskie prawo konstytucyjne. Zarys wykładu. Warszawa: Wydawnictwo Sejmowe.

Granat, M. (2002). Formy konkretnej kontroli konstytucyjności prawa (w państwach Europy Środkowej i Wschodniej). W: M. Kruk, J. Trzciński, J. Wawrzyniak (red.), Konstytucja i władza we współczesnym świecie. Doktryna - Prawo - Praktyka, Prace dedykowane profesorowi Wojciechowi Sokolewiczowi na siedemdziesięciolecie urodzin. Warszawa: Wydawnictwo Sejmowe.

Izdebski, H. (2012). Wykłady w Trybunale: Fundamenty współczesnych państw - wartości, zasady i prawa podstawowe. Obserwator Konstytucyjny. Pobrane z: http://www. obserwatorkonstytucyjny.pl/debaty/wyklady-w-trybunale-fundamenty-wspolczesnychpanstw-wartosci-zasady-i-prawa-podstawowe/.

Jarosz-Żukowska, S. (2010). Charakter i znaczenie wolności i praw jednostki wyrażonych w Rozdziale I Konstytucji RP. W: M. Jabłoński (red.), Wolności i prawa jednostki w Konstytucji RP. Tom I, Idee i zasady przewodnie konstytucyjnej regulacji wolności praw jednostki w RP (s. 107-140). Warszawa: Wyd. C.H BECK.

Kaźmierczak, T. (2011). Partycypacja publiczna: pojęcie, ramy teoretyczne. W: A. Olech (red.), O uczestnictwie obywateli w życiu wspólnoty lokalnej (s. 83-99). Warszawa: Wyd. Instytut Spraw Publicznych.

Komunikat po wyroku TK (2015) z 4 listopada 2015 w sprawie K 1/14 Otwarte fundusze emerytalne (OFE); zasady wypłat emerytur. Pobrane z: http://trybunal.gov.pl/rozprawy/ komunikaty-prasowe/komunikaty-po/art/8679-otwarte-fundusze-emerytalne-ofezasady-wyplat-emerytur/.

Konstytucja Polskiej Rzeczypospolitej Ludowej uchwalona przez Sejm Ustawodawczy w dniu 22 lipca 1952, Dz.U. RP Nr 33, poz. 232 (Konstytucja PRL).

Krawczyk, P. (2014). Problem konstytucyjności tzw. ustawy o bestiach. Zeszyty naukowe Uniwersytetu Przyrodniczo-Humanistycznego w Siedlcach, 100. 
Kuciński, J. (2003). Konstytucyjny ustrój państwowy Rzeczypospolitej Polskiej. Warszawa: Wydawnictwo Prawnicze LexisNexis.

Kustra, A., Bień-Kacała, A. (2009). Trybunał Konstytucyjny i Trybunał Stanu. W: Z. Witkowski, J. Galster, B. Gronowska, i in. (red.), Prawo konstytucyjne (s. 479-541). Toruń: Wyd. TNOiK.

Ławniczak, A. (2010). Wolności i prawa człowieka w ujęciu konstytucyjnym. W: M. Jabłoński (red.), Wolności i prawa jednostki w Konstytucji RP. Tom I, Idee i zasady przewodnie konstytucyjnej regulacji wolności praw jednostki w RP (s. 141-177). Warszawa: Wyd. C.H BECK.

Łętowska, E. (2016). O tym, co boli sędziów i co boli sądzonych. Pobrane z: http://www. lex.pl/czytaj/-/artykul/prof-letowska-o-tym-co-boli-sedziow-i-co-boli-sadzonych.

Piotrowski, R., Ochmann, P., Pisz, M. (red.). (2014). Prawo konstytucyjne. Kompendium. Warszawa: Wyd. C.H. BECK.

Potorski, R. (2011). Europejski nakaz aresztowania i jego implementacja w wybranych krajach Unii Europejskiej. W: R. Potorski (red.), Współpraca policyjna i sądowa w sprawach karnych w Unii Europejskiej. Geneza, struktury, działania (s. 175-201). Toruń: Wyd. Adam Marszałek.

Skrzydło, W. (2002). Rola Trybunału konstytucyjnego w rozstrzyganiu sporów kompetencyjnych. W: M. Kruk, J. Trzciński, J. Wawrzyniak (red.), Konstytucja i władza we współczesnym świecie. Doktryna - Prawo - Praktyka, Prace dedykowane profesorowi Wojciechowi Sokolewiczowi na siedemdziesięciolecie urodzin (s. 484-493). Warszawa: Wydawnictwo Sejmowe.

Sześciło, D. (2016). Po co ci człowieku trójpodział władzy, Obserwator Konstytucyjny. Pobrane z: http://www.obserwatorkonstytucyjny.pl/artykul/po-co-ci-czlowieku-trojpodzial-wladzy/.

Traktat z dnia 16 kwietnia 2003 podpisano w Atenach dotyczący przystąpienia dziesięciu państw, w tym Polski, do Unii Europejskiej, Dz.U. RP z 2004 Nr 90, poz. 864 (Traktat Akcesyjny).

Trybunał Konstytucyjny, Dane statystyczne z działalności. Pobrane z: http://trybunal.gov. pl/sprawy-w-trybunale/statystyka/ (TK-statystyka, 2016).

Uliasz, J. (2011). Władza sądownicza wobec partii politycznych w Polsce - zagadnienia wybrane. Przegląd Prawa Konstytucyjnego, 2. Pobrane z: http://www.marszalek.com. pl/przegladprawakonstytucyjnego/ppk6/05.pdf.

Ustawa (1969/94) z dnia 19 kwietnia 1969 kodeks karny, Dz.U. RP 1969 nr 13 poz. 94 (stan z 1989 roku).

Ustawa (1982/83) z dnia 26 marca 1982 o zmianie Konstytucji Polskiej Rzeczypospolitej Ludowej, Dz.U. RP 1982 nr 11 poz. 83.

Ustawa (1996/464) z dnia 5 grudnia 1996 r. o zawodach lekarza i lekarza dentysty, Dz.U. RP z 2015 poz. 464.

Ustawa (1997/483) z dnia 2 kwietnia 1997 Konstytucja Rzeczypospolitej Polskiej, Dz.U.

RP Nr 78, poz. 483 z późn. zm. (Konstytucja RP).

Ustawa (1997/643) z dnia 1 sierpnia 1997 o Trybunale Konstytucyjnym, Dz.U. RP Nr 102, poz. 643, z późn. zm. 
Ustawa (2013/397) z dnia 5 lipca 1990 prawo o zgromadzeniach, Dz.U. RP z 2013 poz. 397 (stan na 2013 rok).

Ustawa (2014/24) z dnia 22 listopada 2013 o postępowaniu wobec osób z zaburzeniami psychicznymi stwarzających zagrożenie życia, zdrowia lub wolności seksualnej innych osób, Dz.U. RP 2014, poz. 24 (ustawa o bestiach).

Ustawa (2015/128) z dnia 29 sierpnia 1997 - Prawo bankowe, Dz.U. RP z 2015 poz. 128 (stan na 2015 rok).

Ustawa (2015/541) z dnia 20 marca 2015 o zmianie ustawy - kodeks karny oraz niektórych innych ustaw, Dz.U. RP z 2015 poz. 541.

Wyrok Trybunału Konstytucyjnego (2005a) z dnia z 11 maja 2005 w sprawie TK K 18/04 Traktat Akcesyjny Polski do UE, Dz.U. RP z 2005 Nr 86, poz. 744.

Wyrok Trybunału Konstytucyjnego (2005b) z dnia z 27 kwietnia 2005 w sprawie P 1/05 dotyczący Europejskiego Nakazu Aresztowania, Dz.U. RP z 2005 Nr 77, poz. 680.

Wyrok Trybunału Konstytucyjnego (2011) z dnia 16 marca 2011 w sprawie K 35/08 dotyczący Dekretu o stanie wojennym, Dz.U. RP z 2011 Nr 64, poz. 342.

Wyrok Trybunału Konstytucyjnego (2014) z dnia 18 września 2014 w sprawie K 44/12 dotyczący ustawy z dnia 5 lipca 1990 r. - Prawo o zgromadzeniach Dz.U. RP z 2014 poz. 1327.

Wyrok Trybunału Konstytucyjnego (2015a) z dnia 14 kwietnia 2015 w sprawie P 45/12 dotyczący kierowania przez banki wierzytelności do postępowania egzekucyjnego z pominięciem sądowego postępowania rozpoznawczego, Dz.U. RP z 2015 poz. 559. Wyrok Trybunału Konstytucyjnego (2015b) z dnia z 7 października 2015 w sprawie K 12/14 dotyczący Prawa do odmowy wykonania świadczenia zdrowotnego niezgodnego z sumieniem („klauzula sumienia”), Dz.U. RP z 2015 poz. 1633.

Wyrok Trybunału Konstytucyjnego (2015c) z dnia z dnia 4 listopada 2015 w sprawie K 1/14 dotyczący Otwartych Funduszy Emerytalnych (OFE); zasady wypłat emerytur, Dz.U. RP z 2015 poz. 1917.

Wyrok Trybunału Konstytucyjnego (2016a) z dnia 11 listopada 2016 w sprawie K 24/15 dotyczący zasad zatrzymania prawa jazdy, OTK ZU nr A/2016, poz. 77.

Wyrok Trybunału Konstytucyjnego (2016b) z dnia 23 listopada 2016 w sprawie K 6/14 dotyczący ustawy o postępowaniu wobec osób z zaburzeniami psychicznymi stwarzających zagrożenie życia, zdrowia lub wolności seksualnej innych osób, http://ipo. trybunal.gov.pl/ipo/Sprawa?cid=1\&dokument=14919\&sprawa=12896. 